DOI https://doi.org/10.30525/978-9934-26-110-7-12

\title{
ЗНАКИ ВІЙНИ: ДО ПИТАННЯ СИМВОЛІКИ У СУЧАСНИХ ВОСННИХ ТВОРАХ
}

\author{
Кулінська Я. I. \\ кандидат філологічних наук, доцент, \\ доиент кафедри україністики \\ Начіональний медичний університет імені О. О. Богомольия \\ м. Київ, Украӥна
}

Російсько-українська війна на Сході України стала потужним двигуном вітчизняного літпроцесу: повернула до обігу давно не використовувані жанри й напрямки, активувала появу нових письменницьких імен і творів - разом із ними до сучасної літератури увійшли нові теми, поняття й герої, нові образи й символіка загалом. Усе разом потребує системного комплексного вивчення й ретельного аналізу науковців: досі цих тем, попри їхню суспільну значущість, фахівці торкалися лише епізодично.

Мета нашої роботи - розглянути сучасні воєнні твори, зокрема повість В. Шкляра «Чорне сонце», роман С. Жадана «Інтернат», «Іловайський щоденник» Р. Зіненка (2020), «Щоденник добровольця батальйону «Донбас» I. Михайлишина (2020), визначити в текстах сучасні знаки-символи, дослідити особливості їхньої появи, природи та функціонування.

У Літературознавчому словнику-довіднику символ пояснюється як «предметний або словесний знак, який опосередковано виражає сутність певного явища, має філософську смислову наповненість» $[8$, c. 635].

Таке визначення, на нашу думку, $є$ найточнішим, тож ми спиратимемося на нього під час нашої наукової розвідки.

В українській літературі й світоглядно-творчій парадигмі письменників, чи не найважливіше місце здавна посідала солярна й флористична символіка [9]. На думку О. Веселовського, це свідчить передовсім про анімізм українців, їхню віру в одухотворення явищ природи [55, с. 49]. Бо саме через символічно-смислове значення квітів і дерев народ кілька століть поспіль розкриває свою світоглядну парадигму.

Слід зазначити, що солярна й рослинна символіка репрезентована чи не найбільше і в сучасних армійських текстах. Щоправда, смислове іiі значення істотно відрізняється від традиційного. 
Приміром, хрестоматійний мотив сонцепоклонництва і образ самого Сонця як одного $з$ домінантних життєдайних символів для всього сущого на землі, як його артикулювали в класичній літературі Л. Українка, М. Коцюбинський, О. Олесь, Г. Чупринка, М. Філянський, М. Вороний у сучасній воєнній прозі не представлено.

Натомість в комбатанських текстах йдеться про зміну значення цього образу, наповнення його новим значенням і новими функціями: «I стояло наді мною високо в зеніті сонце, я дивився на нього $і$ зовсім не мружився, бо воно не пекло, не палило і вже не світило. Сонце було чорне. Воно увійшло в Сварогову ніч, увійшло в саму сериевину ночі Сварога...» $[10$, с. 46$]$. Сонце - солярний знак вічності й безперервності життя на землі перетворюється на магічний символ покарання тим, хто забувся голос прабатьків, не чув голосу рідної крові, образ сонця наділений у воєнній повісті вищим призначенням знищити відступників.

Змінюється у сучасній воєнній прозі і зміст солярного символу вогню. У армійських щоденниках цей образ, зокрема, трансформується на руйнівну силу, пекельне полум'я: «...Вони померли в агонії. У пекельній агонії. Вогонь випалив усе. Вогонь усюди. І сонямники...» [6, с. 311]; чи на свічку за полеглими «будинок, щяо горить. Він як далека свічка. Свічка за всіма загиблими..» [6, с. 315].

Широко репрезентовано у сучасній воєнній літературі (і в назвах творів, як-от, А. Зелінський «Соняхи. Духовність під час війни», «Війна у соняшниках. Позивний Крим» та ін., і в самих армійських текстах) образ флористичного сонця - соняха: 3 буденним значенням, і 3 новим, набутим під час воєнної кампанії 2014-го року. Традиційно рослина поєднує дві енергетики: 3 магічною божественною силою (через короноподібну форму й жовтий колір), і земною, адже уособлює небесне світило на землі. Окрім цього, для українців соняшник - ще й один із образів Батьківщини, символ родючості та процвітання [7].

Спільним для зображення соняшника і в документальній (воєнні щоденники), $\mathrm{i}$ для сучасної художньої прози так само $\epsilon$ нова наповненість символу, нові асоціації з ним у колишніх i чинних комбатантів. Ось приміром, в «Іловайському щоденнику» Р. Зіненка розповідь, як бійці їдуть соняшниковим полем: «... Кілька одиниць бронетехніки торували гусенииями соняшники, а решта колони прямувала слідом...<> Ліворуч та праворуч нічого не було видно, крім сухих стебел та головок з насіння, під колесами, поверх сухої землі, лежали поламані й трохи прим'яті стебла сонямників...» [5, с. 207].

Органічну єдність 3 природою, зв'язок 3 божественним началом людини - наразі перервано, зламані соняхи у воєнному щоденнику 
Р. Зіненка - знак невідворотності буремного лихоліття для України, коли найкращі ії сини-патріоти можуть полягти в боях, захищаючи Вітчизну.

Тож соняшник 3 традиційного життєдайного образу, символу родючості й гармонії людської природи під впливом суспільних катаклізмів змінює своє значення й асоціюється у бійців із запеклими сутичками й втратами: "Танк, щяо вийшов за нами, не став ӥхати трунтовкою, а одразу виїхав на поле... <> Потім суиільний безлад. Підбитий транспорт. 3'їд у гущавину сонямників. Вибухи з усіх боків... <> Авто буксує в заростях сонямника ...» [5, с. 213].

Сонце й соняшники викликають галюцинації у бійця Маляра, героя повісті В. Шкляра «Чорне сонце»: «Я подивився у дальній кінець дороги, обіч якої достигали соняшники, і мені привиділися два генерали. Вони повагом ішли в наш бік, сяючи погонами проти сония. Фата-моргана. Це через соняшники. Я почувався божевільним Ван-Гогом, якому сонще напекло голову...» [10, с. 37].

А в армійському щоденнику I. Михайлишина соняшник постає алегоричним символом Смерті: «... I соняшники. Бісові соняшники! Ненавиджу вас ще більше... <> Ці соняшники ховали під собою ворожі трупи. Від вибухів тіла наших бійців також залітали в иі соняхи. Тепер вони там перемішані. Чортові соняхи. Ви уявляєте собі смерть? Вона з косою? Це неправда. Смерть ходить зі стеблом соняха...» [6, с. 310].

Цей флористичний образ використовує у вірші прозою «Соняхи» $\mathrm{i}$ сучасний письменник Б. Гуменюк: рослини тут - полеглі воїни: «...соняхи гинули як солдати, їм не було куди сховатися у чистому полі, $y$ них не було саперних лопаток, щуоб окопатися, ті, яким щзастило вціліти після обстрілу, опускали голови додолу, щьоб не дивитися на загиблих товаришів. За війну соняхи навчилися повертати голови не у бік сония, що природно, а туди, де гримить, туди де горить...» [3]. 3 їхнього насіння проростуть інші покоління українців, хай не таких мужніх бійців, однак вони, як і їхні славні предки, боронитимуть рідну землю; за автором, це - спадкоємність поколінь: «Коли підійти ближче $i$ роздивитися, то можна помітити, що поряд з кожним молодим соняхом досі стоїть старий, минулорічний, обезголовлений, посічений осколками, попалений, як тінь. Поряд із живим стоїть мертвий, підпирає його, дає йому опору, прикриває його своӥм тілом, якого, коли дивитися здалеку, спериу навіть не видно. Але він - $\epsilon$, він - стойть» [3].

Не оминає соняшників і С. Жадан у романі «Інтернат», щоправда вони в нього 3 національного символу праці й добробуту перетворюються спершу на знак втрачених ілюзій, а згодом на потребу морального вибору, бо його герой, вчитель української мови та літератури 
в одному з донбаських селищ, мусить нарешті визначитися зі своїм майбутнім і громадянською відповідальністю: «Попереду чорніє соняшникове поле, з незібраним минулорічним урожаєм. Темні висушені за літо соняшники схожі на вигорілий ліс... Лишилося пройти крізь соняхи... Соняшники розступаються, боляче б'ють по руках, вода затікає до рукавів. Так і стоятимуть, думає Паша про соняшники, як зомбі. Забуті й прокляті. Доки хтось усе ие не переоре...» [4, с. 171].

До слова, є в «Іловайському щоденнику» Р. Зіненка й образ розораного поля - символ кардинальних змін і нових перспектив у житті $[5$, c. 242$]$.

Окрім образу соняшника, заявлені в комбатанських творах (наскрізні в повісті В. Шкляра «Чорне сонце») і флористичні образи верби (символ материнського дому й дитинства, туги й материнських сліз) та тополі (хоробрі лицарі-козаки, трагічна доля і заразом метафора гідного, шляхетного життя): саме ці дерева - так само часто згадувані і в народних переказах, і в класичній літературі.

Зустрічаються в армійській прозі, щоправда поодинокі, й орнітологічні символи, приміром, голуб в «ловайському щоденнику» Р. Зіненка: «...мені на шляху трапилася зграйка голубів. Більшість птахів встигли злетіти, а один голуб забарився й потрапив під бампер «халка», шо мчав на шаленій швидкості. У мене тоді промайнула думка, що вбитий птах є поганою прикметою, та наступної миті голуб вирвався з-під авто й полетів уперед, обганяючи мій автомобіль. Тоді я дуже ясно відчув, що ией голуб - я сам. I щзо я також врятуюся від неминучої біди...» [5, с. 95].

Підбиваючи підсумки, зауважимо: у сучасній армійській прозі (воєнні щоденники Р. Зіненка й І. Михайлишина), художніх творах В. Шкляра (повість «Чорне сонце») й романі С. Жадана «Інтернат» найбільше представлені солярні й флористичні образи, хоча деякі автори послуговуються й орнітологічними образами.

У частині текстів у символах змінюється їхнє традиційне значення й оприявнюється нове, набуте під час розгортання російсько-української війни. Так, класичний образ Сонця втрачає своє значення життєдайного й божественного світила й перетворюється на Чорне сонце - містичний знак для покарання тих, хто забув своє призначення - у часи воєнного лихоліття боронити Батьківщину; соняшник стає символом запеклих боїв і втрат, а також алегоричним образом Смерті (I. Михайлишин).

Водночас хрестоматійні флористичні образи верби й тополі як символи рідного краю, дому й материнської печалі за дітьми презентовані у сучасній прозі практично без змін. 


\title{
Література:
}

1. Анімізм. Вікіпедія. URL: https://uk.wikipedia.org/wiki/\%D0\%9 0\%D0\%BD $\% \mathrm{D} 1 \% 96 \% \mathrm{D} 0 \% \mathrm{BC} \% \mathrm{D} 1 \% 96 \% \mathrm{D} 0 \% \mathrm{~B} 7 \% \mathrm{D} 0 \% \mathrm{BC}$ звертання: 28.06.21)

2. Веселовский А. Миф и символ. Русский фольклор. Ленинград: Наука, 1979. Т. ХІХ: Вопросы теории фольклора. С. 186-199.

3. Гуменюк Б. Соняхи. Блокпост. URL: https://www.facebook.com/ 690230277770764/posts/846681388792318/ (дата звертання: 30.06.21).

4. Жадан С. Інтернат. Чернівці: Meridian Czernowitz, 2017. 336 c.

5. Зіненко Р. Іловайський щоденник. Харків: Видавництво «Фоліо». 2020. 282 с. (Серія «Воєнні щоденники»).

6. Михайлишин I. «Танець смерті. Щоденник добровольця батальйону «Донбас». Харків: Фоліо, 2020. Серія «Воєнні щоденники». 315 с.

7. Міліана. Соняшник як символ. URL: https:// ukraine. ejournal.com/ 461123.html (дата звертання: 24.06.21).

8. Символ. Літературознавчий словник-довідник. Р.Т. Гром'як, Ю.І. Ковалів та ін. Київ: ВЦ «Академія», 1997. С. 365.

9. Цуркан I. Лірика Олександра Олеся: поетика символізму. URL: https://shron1.chtyvo.org.ua/Tsurkan_Ihor/Liryka_Oleksandra_Olesia_ poetyka_symvolizmu.pdf? (дата звертання: 24.06.21).

10. Шкляр В. Чорне сонце: збірка. Харків: Клуб сімейного дозвілля, 2015. $304 \mathrm{c}$.

DOI https://doi.org/10.30525/978-9934-26-110-7-13

\section{POPULARIZATION OF UKRAINIAN LITERATURE BY UKRAINIAN WRITERS ABROAD}

\author{
Lychuk S. V. \\ Candidate of Philological Sciences, \\ Associate Professor at the Department of Linguistics \\ Ivano-Frankivsk National Medical University \\ Ivano-Frankivsk, Ukraine
}

Distribution of Ukrainian products abroad. Undoubtedly, the publishing houses play an important role in the dissemination of translated literature. We can talk about various forms of support for the translation of Ukrainian literature in English from outside Ukraine. This is the publication of the literary almanac of the youngest generation of Ukrainian 